\title{
Piriformis syndrome occurring after pregnancy
}

\author{
Ali Kemal Sivrioglu, ${ }^{1}$ Selahattin Ozyurek, ${ }^{2}$ Hakan Mutlu, ${ }^{3}$ Guner Sonmez ${ }^{1}$
}

${ }^{1}$ Department of Radiology, Aksaz Military Hospital, Mugla, Turkey

${ }^{2}$ Department of Orthopedic Surgery, Aksaz Military Hospital, Mugla, Istanbul, Turkey

${ }^{3}$ Department of Radiology, GATA Haydarpasa Teaching Hospital, Istanbul, Turkey

\section{Correspondence to} Dr Ali Kemal Sivrioglu, draksivrioglu@gmail.com
To cite: Sivrioglu AK, Ozyurek S, Mutlu $\mathrm{H}$, et al. BMJ Case Rep Published online: [please include Day Month Year] doi:10.1136/ bcr-2013-008946

\section{DESCRIPTION}

A 27-year-old woman was referred to an orthopaedic surgeon for pain in the left buttock radiating to the posterior thigh, previously, which had been increasing during 3 months after pregnancy (a term singleton, normal birth weight). The patient's pain increased after prolonged sitting, walking, and climbing stairs. Upon physical examination, flexing the hip at $90^{\circ}$ and adducting across the midline with deep digital palpation, severe tenderness and pain in the left piriformis muscle was observed. Passive internal rotation of the left thigh caused pain (Freiberg's sign), as did resistance to abduction and external rotation of the right thigh (Pace's sign) and voluntary adduction, flexion and internal rotation of the hip (Lasègue's sign).

On coronal T1-weighted MRI, asymmetrical thickening of the left piriformis muscle was seen compared with the right (figure 1A). Thickness and hyperintensity of the left piriformis muscle were observed on axial and coronal T2-weighted images (figures 1B and 2). There was also oedema adjacent to the lower portion of the left sacroiliac joint. Hyperintensity compatible with oedema was also seen in the soft tissue around the left piriformis muscle. These findings were consistent with piriformis syndrome. Physiotherapy and symptomatic drug treatment significantly decreased the patient's complaints.

Piriformis syndrome is a rare cause of lower back pain and sciatica owing to sciatic nerve entrapment at the greater sciatic notch. ${ }^{1}$ Approximately $6 \%$ of lower back pain and sciatica cases may be seen in a general practice. $^{2}$ During pregnancy, the gluteal muscle group of the hip/pelvis is elongated and strained, especially the deep, small muscles of the hip/pelvis including piriformis. ${ }^{3}$ Piriformis syndrome should be suspected in any patient with symptoms of hip or sciatic pain especially after pregnancy.

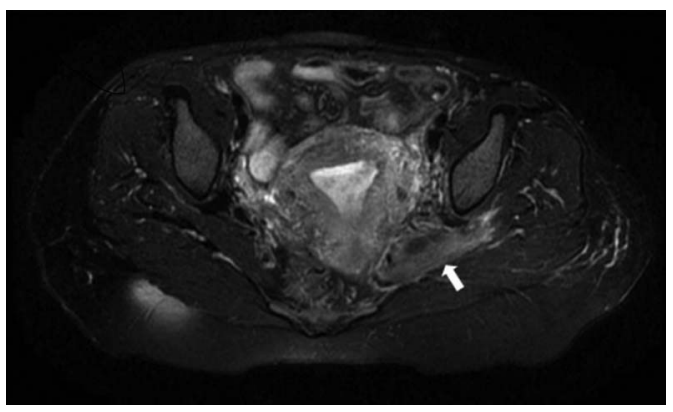

Figure 2 Axial T2-weighted image also shows thickness and hyperintensity of the left piriformis muscle (arrowhead). Moreover, hyperintensity compatible with oedema shows soft tissue around the left piriformis muscle.

\section{Learning points}

- Piriformis syndrome, frequently underdiagnosed in the obstetric population, should be suspected in any patient with symptoms of hip or sciatic pain.

- In suspected cases, MRI should be requested initially to make a definitive diagnosis while ruling out other causes of lower back pain. Other imaging modalities may not likely show the presence of abnormality.

- Asymmetrical thickening of piriformis muscle and $\mathrm{T} 2$ hyperintensity are frequently seen on MRI.

\section{Competing interests None.}

Patient consent Obtained.

Provenance and peer review Not commissioned; externally peer reviewed. 


\section{REFERENCES}

1 Ozaki S, Hamabe T, Muro T. Piriformis syndrome resulting from an anomalous relationship between the sciatic nerve and piriformis muscle. Orthopedics 1999;22:771-2.
2 Lee $\mathrm{YL}$, Margherita AJ, Gierada DS, et al. MRI of piriformis syndrome. AJR Am J Roentgenol 2004;183:63-4.

3 Vallejo MC, Mariano DJ, Kaul B, et al. Piriformis syndrome in a patient after cesarean section under spinal anesthesia. Reg Anesth Pain Med 2004;29:364-7.

Copyright 2013 BMJ Publishing Group. All rights reserved. For permission to reuse any of this content visit

http://group.bmi.com/group/rights-licensing/permissions.

BMJ Case Report Fellows may re-use this article for personal use and teaching without any further permission.

Become a Fellow of BMJ Case Reports today and you can:

- Submit as many cases as you like

- Enjoy fast sympathetic peer review and rapid publication of accepted articles

- Access all the published articles

- Re-use any of the published material for personal use and teaching without further permission

For information on Institutional Fellowships contact consortiasales@bmjgroup.com

Visit casereports.bmj.com for more articles like this and to become a Fellow 